NBER WORKING PAPER SERIES

WHO SHOULD LEARN WHAT

FROM THE FAILURE AND

DELAYED BAILOUT OF THE ODGF?

Edward J. Kane

Working Paper No. 2260

NATIONAL BUREAU OF ECONOMIC RESEARCH

1050 Massachusetts Avenue

Cambridge, MA 02138

May 1987

The research reported here is part of the NBER's research program in Financial Markets and Monetary Economics. Any opinions expressed are those of the author and not those of the National Bureau of Economic Research. 
NBER Working Paper \#2260

May 1987

Who Should Learn What From the Failure and

Delayed Bailout of the ODGF?

\begin{abstract}
In March 1985, the failure of the Ohio Deposit Guarantee Fund (the ODGF) sent shock waves reverberating through the financial world. This episode is popularly interpreted as evidence of the dangers of both private deposit insurance and continuing financial deregulation. This paper argues that policies of financial deregulation played little role in the ODGF insolvency. The failure of the ODGF was instead a failure of government regulation, rooted in inadequacies in the OGDF information and enforcement systems.
\end{abstract}

The ODGF may be conceived as the Federal Savings and Loan Insurance Corporation writ small. Both agencies share many of the same structural imbalances: large unresolved losses, explicitly mispriced and underreserved services, inadequate information and monitoring systems, insufficient disciplinary powers, and a susceptibility to political pressures to forbear.

Doctors perform autopsies on dead patients to improve their ability to protect living ones. This paper's autopsy of the institutional corpse of the ODGF focuses on identifying the kinds of disturbances that transform structural imbalances into a full-fledged crisis. Our research underscores the way that deceptive accounting and underfinanced insurance funds contain crisis pressures in the short run by setting the stage for more severe problems down the line. As financial markets approach more and more closely the perfect and complete markets beloved by finance theorists, the amount of time that can be bought by policies that merely defer crisis pressures is shrinking and becoming hard to use productively. 
Revised: May 11, 1987

\title{
WHO SHOULD LEARN WHAT FROM THE FAILURE AND DELA YED BAILOUT OF THE ODGF?
}

\author{
Edward J. Kane* \\ The Ohio State University
}

In March 1985, the partial banking holiday associated with the failure of the Ohio Deposit Guarantee Fund (the ODGF) sent shock waves reverberating through the world financial system. These shock waves contributed to the May 1985 failure of the Maryland Savings Share Insurance Corporation (MSSIC) two months later. However, as it became clear that Ohio, Maryland, and federal taxpayers were going to pick up the bill for these failures, the system settled down again.

This paper focuses on the ODGF, portraying it as a small-scale version of the massively undercapitalized Federal Savings and Loan Insurance Corporation (FSLIC). We study the pathology of the ODGF failure and bailout to learn how the ODGF's longstanding economic insolvency degenerated into a crisis of confidence. Given FSLIC's continuing economic insolvency, this knowledge should help us to avoid a replay of ODGF and MSSIC experience on the federal level. At the same time, we need to understand that the ODGF, MSSIC, and FSLIC became insolvent because incentive-incompatible deposit-insurance contracts induce undesirable political, bureaucratic, and private risk-taking behaviors. These incentive defects make the occurrence of de facto insolvences in associated insurance funds inevitable.

*The author is Everett D. Reese Professor of Banking and Monetary Economics and Research Associate, National Bureau of Economic Research. He wishes to thank Ronald Bolton, Benson Hart and Walker Todd for helpful discussions and the Herbert V. Prochnow Educational Foundation for financial support. Opinions expressed are the author's alone and should not be construed to represent those of the Prochnow Foundation or NBER. 
The paper's central thesis is that a worldwide financial disturbance occurred, not because of the OGDF's insolvency, but because State and federal politicians made a surprising (albeit short-lived) attempt to duck out of what the market conjectured to be their responsibility for backing up ODGF resources. The temporary unwillingness of State authorities to make good the losses suffered by ODGF amounted to their calling the equivalent of a timeout to assess the relative willingness of State taxpayers and federal authorities to bear the costs of keeping ODGF-insured depositors whole. In calling a prolonged banking holiday for ODGF institutions instead of immediately recapitalizing the guarantee fund, Ohio's Democratic governor challenged the Republican-controlled State legislature and federal regulators and politicians to a multisided game of chicken. Playing out this game confirmed market participants' longstanding presumption that in a political showdown the concentrated interests of depositors in troubled institutions tend to overcome the diffuse interests of the various taxpayers that the U.S. financial system makes risk-bearers of last resort.

Although the spectacular and corrupt failure of E.S.M. Securities and the imprudently large exposure of Home State Savings Bank to this single credit were the proximate causes of the ODGF's demise, the ultimate cause is the false security that 100-percent ODGF guarantees gave to depositors in Home State Savings Bank and to other ODGF-insured firms. As unrealized losses at ODGF institutions grew increasingly larger than ODGF reserves, this security became more and more illusory because it placed a correspondingly greater burden on State regulators to oversee insured institutions ever more skillfully.

Common sense holds that it is not sensible to depend on others (particularly politicians and bureaucrats) always to act sensibly. In driving one's car, for example, depending on other drivers to behave optimally is a sure formula for eventual disaster. Using this perspective, the paper maintains, not that the 
colorful individuals involved in the ODGF's demise were blameless, but that deposit-insurance incentives sorely and perversely test the limits of participants' moral and financial integrity. No guarantee scheme could endure forever whose information, monitoring, and regulatory-response subsystems led as many politicians, regulators, and S\&L executives so deeply into temptation as the ODGF's did. The analysis develops the premise that only by refusing to let the search for individual scapegoats serve as a political palliative can we make progress on the vital task of building a more durable system of federal deposit insurance.

Adam Smith notes man's natural propensity to truck, barter, and exchange. This paper posits a parallel natural propensity for modern-day politicians and bureaucrats to deny and cover-up massive insolvencies at government-insured financial institutions and to bailout affected parties once a shortage is incontrovertably revealed. Congress' repeated resistance to adequately recapitalizing FSLIC exemplifies this propensity. This proclivity toward deception and myopia is rooted in officials' desire to project a favorable image of their capacity to control the events that fall within their administrative purview, their interest in developing and sharing regulatory rents, and their belief that current taxpayers are relatively insensitive to the deferred costs of following cover-up and bailout policies. Presuming that regulators engage in self-interested, career-enhancing conduct rather than purely altruistic behavior makes it unreasonable for taxpayers to expect public servants charged with managing deposit-institution insolvencies to give them either an honest count or an honest deal. If taxpayers truly want an honest count and an honest deal, they are going to have to demand laws that apply sanctions to public servants that do not promptly disclose information indicative of poor performance. 


\section{Preliminary Concepts: Insol vency, Insol vency Resolution, Runs, and Information Suppression}

Insolvency. Insolvency exists de facto when an institution loses the autonomous capacity to discharge its liabilities. To an economist, this condition is synonymous with an institution's net worth becoming negative. Economic insolvency occurs when the market value of an organization's nonequity liabilities exceeds the market value of its assets. This definition proceeds in terms of the firm's expanded balance sheet, recognizing all explicit and implicit sources of value to the firm and all explicit and implicit nonequity claims against it. To the economist, the idea of an "off-balance-sheet item" is an oxymoron (i.e., a contradiction in terms).

Accountants employ different concepts of insolvency and net worth. For many items, accountants substitute book values (which often embody adjusted or unadjusted historical costs) for market values and typically neglect potentially important categories of assets and liabilities. Rules which dictate permissible substitutions and omissions are embodied in what accountants call "generally accepted accounting principles."

U.S. deposit-institution regulators' closure rules turn on an inherently more discretionary concept of de jure or legal insolvency. This concept is even more amor phous than accounting insolvency. If regulators choose, they may selectively and asymmetrically recognize sources of income or capital gains and defer losses or capitalized costs that generally accepted accounting principles would treat more conservatively. In practice, regulators tend to focus primarily on a troubled institution's liquidity: its capacity to cover its debts as they come due or accrue. Since (except in the most extreme cases of economic insolvency) collateralized last-resort lending from an institution's Federal Reserve or Home Loan Bank can maintain this capacity, using a liquidity criterion puts the legal solvency of deeply troubled firms squarely into the hands of federal officials.

Methods of Insolvency Resolution. When a firm becomes economically insolvent, the downside risk from its continuing operations accrues predominantly to its 
creditors or (when the debt is guaranteed) to its guarantors. Given their exposure to moral hazard in an undercapitalized firm, creditors and guarantors typically insist on covenants that effectively give them the right either to accelerate their claims or to take over an insolvent borrower unless its stockholders promptly inject new capital into its balance sheet.

Because a deposit institution cannot legally operate in an officially insolvent condition, a de jure insolvency forces regulators to close its doors. An institution's formal failure may be resolved in either of three ways: by a liquidation and payoff (in which the proceeds from disposing of the firm's assets are made to satisfy creditors and guarantors), by a private acquirer's undertaking a comprehensive or selective asset-purchase and deposit-assumption transaction, or by a government takeover (which is invariably conceived to be temporary). However, instead of declaring an official insolvency, authorities may demand that stockholders go to private capital markets to recapitalize the firm or act to bailout the firm by providing it or its acquirer explicit or implicit financial assistance on below-market terms. While the concept of explicit financial assistance is a straightforward one, implicit assistance can take many and subtle forms. For a guarantor, the subtlest and quantitatively most important form of assistance consists of turning a blind or nearly blind eye to a debtor's economic insolvency. It is uneconomic for a guarantor to waive takeover options that are effectively "in the money" without negotiating a balancing quid pro quo. Such benign neglect implicitly transfers capital funds from the guarantor (in this case, the Ohio taxpayer) to managers, stockholders, and unguaranteed creditors of the insolvent firm. Moreover, such neglect sets up incentives for managers of the decapitalized firm to engage in risky endgame plays that tend to increase the value of the implicit transfer the longer and more completely the guarantor forbears from intervening to control its exposure to losses from the firm's continuing operations. Forbearance occurs 
primarily because agents that are supposed to act on behalf of the guarantor find it in their own career interest to try to deny, cover up, or use taxpayer resources to buy their way out of particular classes of insolvency.

Home State Savings was destroyed primarily by $\$ 145$ million in losses incurred through inappropriately heavy and potentially corrupt lending to E.S.M. Securities, Inc. (ESM). Examiners for the State first discovered this problem in 1980 when losses were still small and went on to recommend strong and immediate action. For several years before its 1985 failure, Home State Savings was economically insolvent. The not-insubstantial value of its stock traced to its managers' ability to keep ODGF and State officials from closing the firm. Although Home State's de facto insolvency and its exposure to further losses in ESM were recognized by State examiners, the State's regulatory braintrust chose not to enforce in full the economic interests of other ODGF's members and Ohio taxpayers. It settled for negotiating a series of nonbinding supervisory agreements that, until March 1985, Home State's management abrogated with virtual impunity. Instead of getting tough with Home State management and stockholders, political appointees at the head of the relevant state agency repeatedly temporized, leaving the problem festering for their successor. As Home State's difficulties grew in size and complexity, the situation became as hard to handle as a box of unstable explosives.

Runs. What finally forced the closure of Home State Savings was a depositor run. In talking about the abstract problem of depositor runs, authorities invariably focus on the concept of an irrational run. An irrational run occurs when, in response to false rumors, a substantial percentage of depositors try at the same time to 
remove their deposits from an economically solvent deposit institution. Such a run can be stopped by a credible flow of accurate information. Customers waste resources in that they would never have engaged in panic withdrawals if they could have been reliably informed about the institution's true condition.

In the face of concealed insolvencies, deposit-institution managers and regulators would be better-advised to contemplate the dangers of rational runs. In March 1985, the runs experienced in Ohio were rational, not irrational. They were based on quick-breaking information, not on inaccurate rumors. The largest institution in an insurance pool became economically so insolvent that its unrealized losses exceeded the insurance fund set up to support not only the deposits of this large firm, but also those issued by other members of what was a State-sponsored insurance pool. As news of this firm's problem began to reach the public, depositors lined up to withdraw funds first from the massively insolvent firm (and from a second, sister institution) and eventually from several of the weakest other institutions in the pool. Similar problems encountered in other state-sponsored systems are described by Saulsbury (1985).

In a rational run, the time and trouble of wending one's way through a long queue is not wasted. It represents an investment in preserving one's wealth. This is because anyone who manages to withdraw his or her deposits before an insolvency is officially declared is able to escape whole. Absenting government bailouts, depositors of record as of the instant an institution is closed have to absorb net insufficiencies in its and its guarantors' resources.

ODGF member associations were required to hold a reserve with the ODGF equal to two percent of their outstanding deposits. Although these institutions were weakened by secular increases in interest rates and by the direct loss of roughly one third of their accounting net worth in the ODGF bankruptcy, the run on their deposits was directly occasioned by the unexpected reaction of Ohio politicians to the official discovery of Home State Savings' insolvency. 
In Ohio, at the beginning of the run, authorities acted as if it were an irrational one. Depsite their lack of access to good information on the current extent of Home State's insolvency, State officials dared to presume that the ODGF could keep even its weakest client in operation. When the ODGF proved unable to demonstrate the truth of that claim, for almost a week politicians dared to presume that they could easily (i.e., at little cost to the Ohio taxpayer) support the deposits of all but the massively insolvent Home State. Instead of backstopping the resources of ODGF or its member institutions, State authorities declared the ODGF bankrupt, and the governor and legislature set up a new and grossly undercapitalized insurance fund to support the deposits of surviving ODGF members. Given the lack of private economic equity in many of the surviving ODGF member institutions, the resulting deterioration in the perceived (or conjectural) backing that Ohio politicians appeared to offer depositors in the wake of the Home State failure made it eminently rational for depositors to line up to take their savings out of the weakest of the Ohio-insured S\&Ls.

When it became clear that many of the other ODGF firms might have to be closed at potentially great depositor or taxpayer expense, the governor decided to suspend operations at all 70 ODGF-insured institutions. The ostensible purpose of this partial banking holiday was to keep all existing depositors on an equal footing while buying time for a massive task force of examiners (borrowed largely from federal agencies) to develop reliable information by which which regulators could distinguish the set of roughly 20 hopelessly insolvent ODGF firms from the rest of the pool. However, I believe that, consciously or unconsciously, this unexpected and apparently panicky move had two deeper purposes. These purposes were to put the ball into the Republican legislature's court and to pressure federal officials to relieve Ohio taxpayers by contributing financial resources to an ODGF bailout. 
I draw this inference for three reasons. First, the absence of adequate accounting information on the condition of individual institutions cannot justify a decision to punish the managers, stockholders, and customers of the 48 sound and the 20 unsound ODGF members alike. A more proportioned response would be to impose dollar and frequency limits on depositors' withdrawal rights at ODGF firms or to suspend operations only at firms whose solvency definitely appeared questionable. Second, the move's broader effects were almost certainly anticipated. By increasing market participants' rational expectations of the probability that federal authorities might similarly mishandle pressures on the federal insurance funds, the banking holiday could be expected to weaken the dollar on foreign-exchange markets and to raise deposit rates at federally insured banks and S\&Ls. Extending the damage to out-of-state parties seems a likely strategy for loosening federal purse strings. Third, the alternative to this interpretation is to presume that Ohio officials created so much havoc foolishly or incompetently.

Information Suppression. The element in the ODGF regulatory system that most facilitated the coverup and most complicated the resolution of the ODGF's insolvency is its reliance on historical-cost accounting. Post-1980 deregulation of deposit rates could not have had a major effect on the net worth of ODGF-insured institutions. Data analysis (to be undertaken for a later draft) should show that these institutions, which were not subject to federal deposit-rate ceilings, had been paying market rates of explicit interest throughout the 1970s and 1980s. At best, they faced a shift of the focus of FSLIC-insured institutions' future competition from implicit deposit rates (i.e., service and merchandise premiums) to explicit deposit rates.

It is important to recognize that weaknesses in the ODGF information system were design defects and not acts of God. If a system of market-value reporting 
had been in place and examiner ratings were public information, other ODGF members would have felt strong economic pressure to help with the prefailure monitoring of Home State and State officials could have determined far more quickly and more simply which of the 68 non-Home-State institutions were strong enough to survive without a sizeable government bailout. The determination would have been simpler because the primary task would have become to detect the presence or absence of fraudulent or flawed appraisals. This could have been accomplished by checking each firm's records on a sampling basis. Solvent firms whose appraisals checked out and those whose estimated irregularities did not exhaust the institution's capital could have been reopened promptly. In this way, customers and managers of strong, well-managed firms could have been spared considerable suffering and examiner and regulatory resources could have been concentrated on weak and badly managed institutions. As things were, with book values based on historical cost, meaningful balance sheets for each institution had to be produced virtually from scratch.

It is also important to note that, in the absence of ODGF or federal guarantees, the 68 S\&Ls in question would have had to release on a regular basis information sufficient to convince potential depositors of their continuing solvency. By assigning to State employees the task of examining in secret ODGF institutions for insolvency, State officials reduced the natural interest of depositors and other members of the ODGF insurance pool in receiving timely information on the financial condition and investment strategies of ODGF-insured firms. This effectively relieved deposit-institution managers of responsibility for communicating such information to their customers and cross-guarantors.

Another way to see both the rationality of the March, 1985 run on ODGF institutions and the way that ODGF guarantees and confidential monitoring reduced the quality of the information that insured S\&ls passed on to their 
depositors and cross-guarantors is to look at the experience of the six completely uninsured S\&Ls that operated in Ohio at this time. To compete with governmentguaranteed firms, market discipline had long ago forced these firms to indicate what their policies and financial condition were. One thrift (founded in 1895) had a resolute and well-publicized policy of demanding 35 percent equity on its mortgage loans, of never making a mortgage loan that was more than 15 years in initial maturity, and of employing a number of other well-publicized safeguards. Customers could clearly see that its cautious approach to mortgage lending preserved the market value of its net worth. This institution was able to gain deposits when state-insured institutions in other states were losing them and when metal safes in which to store currency at home became impossible to buy locally.

Whenever a government-sponsored insurance corporation parcels out essential risk-management functions to government employees, the electorate is going to hold politicians responsible to some extent for any problems that ensue. This means that, no matter how long it took Ohio politicians to recognize it, the public perceived the State to be backstopping ODGF resources.

In view of such perceptions, why do state and federal politicians permit regulators to suppress information on the condition of insured deposit institutions? The short answer is that suppressing this information shields elected politicians from timely criticism for poor monitoring and regulatory performance. It also increases the credibility of politicians' attempts to deny responsibility for any mistakes that do emerge and leaves them asymmetrically free to bring forward information on whatever regulatory successes their regulatory agents may have achieved. In effect, restricting the flow of relevant information lessens market pressure on politicians and regulators and creates rents for them to share. After reviewing the details of the ODGF crisis, we return to this issue. 


\section{Chronology of ODGF Crisis and Its Resolution}

Table 1 provides a rough chronology of salient events in the development and resolution of the ODGF crisis. This chronology suggests, once ESM's insolvency surfaced, that ESM, Home State, and the ODGF fell like a line of dominoes. It supports the view that the failure of the ODGF was a failure not of private enterprise, but of government regulation -a failure whose resolution was made more difficult by inadequacies in the ODGF information and regulatory-response system. Contrary to one popularly held view, federal policies of financial deregulation played little role in bringing about the failures of either ESM, Home State, or the ODGF.

The chronology is also consistent with at least six potential generalizations. First, economic insolvencies at thrift institutions and at deposit insurers seldom develop overnight and of ten involve regulatory failure and managerial fraud. ESM was insolvent de facto for at least six years and engaged in questionable transactions from its very inception. Second, weaknesses in an insurer's information, monitoring, and regulatory-response system encourage even honest managers of economically insolvent firms to speculate more and more boldly the longer a de facto insolvency persists. Third, information on the unsafe and unsound practices of individual firms uncovered by private accountants and federal investigators does not flow freely to state regulatory bureaus or to managers and depositors of statechartered S\&Ls. Fourth, once an insolvency is discovered, top regulators and elected politicians as short-termers have career-oriented incentives to deny and cover up the insolvency. The costs of deferring the distribution of insolvency losses may be hidden from taxpayers for at least several years and the blame for the problem may even be shifted to representatives of the rival party, while confronting the insolvency directly could unfairly damage politicians' and bureaucrats' professional reputations and re-employability in the private sector. Fifth, 


\section{CHRONOLOGY OF ODGF CRISIS AND ITS RESOLUTION}

1. ESM and Home State Savings

1975: ESM incorporated; announced strategy is to make sophisticated financial plays via repurchase agreements.

Late 1976: U.S. Comptroller of the Currency finds apparent fraud at ESM. Forces a Florida bank to unwind its dealings with it. Puts ESM on a federal blacklist.

1977-1981: ESM under investigation by SEC. Investigation was finally dropped as too troublesome because the firm fought the agency so tenaciously.

1979: Outside Alexander Grant \& Co. accountant learns of fictitious transactions. Accepts loans from an ESM official.

June 2, 1982: Home State concentration of loans with ESM clearly surfaces as an issue at Ohio regulatory agency. (9-3-85 WSJ dates surfacing in draft examination report in October 1982 by Sylvester Hentschel.) Examiner's recommendations are overridden. Home State managers repeatedly promise to reduce their exposure in this credit and repeatedly renege on these promises.

January 28, 1985: Warner's personal balance-sheet position of $\$ 4.85$ million is closed out at ESM.

March 4, 1985: ESM fails, $\$ 300$ to $\$ 350$ million short.

2. The Failure of Home State Savings

March 6-8, 1985: Home State has cumulative deposit outflow of more than $\$ 150$ million.

March 8, 1985: Home State signs borrowing agreement with Cleveland Fed and takes out first loan. Announces decision to leave offices closed on Saturday, March 9.

March 9, 1985: An insolvency of roughly $\$ 150 \mathrm{mil}$. found in ESM. Governor appoints conservator, claims to assign ODGF resources of roughly $\$ 134 \mathrm{mil}$. completely to Home State failure. Loss to other members of ODGF (who had carried their accumulated contributions to ODGF reserves as capital) undermines their solvency.

March 10, 1985: Governor announces Home State will not reopen on Monday.

3. Runs at Other ODGF Members

March 11, 1985: Fed undertakes outreach program to assist surviving ODGF S\&Ls to obtain borrowing documents.

March 13, 1985: Governor and legislat ure establish new fund with $\$ 50$ mil. in state funds and a meaningless $\$ 40 \mathrm{mil}$. from ODGF S\&Ls. Deposit outflows from four surviving ODGF S\&Ls become heavy.

March 14, 1985: Major runs occur at 6 ODGF institutions.

4. Working Out the Terms of the ODGF Bailout

March 15, 1985: Banking Holiday (Contrasts ironically with image of fun and celebration as in film title, Holiday On Ice). Governor pats himself on back for providing "strong leadership." Does not necessarily entail "good leadership."

March 15-17, 1985: State officials attempt to solicit bids for closed institutions from in-state and out-of-state bankers.

March 19, 1985: Game of Chicken with Feds ends. FSLIC promises to speed processing of applications from former ODGF-insured S\&Ls.

March 20, 1985: (early AM): Legislature passes bill allowing openings with possibility of limiting customer withdrawals to $\$ 750$ per month and authorizing indemnification of FSLIC for loss incurred in ODGF S\&Ls through July 1 , 
1986 or 1987. Availability of Fed discount assistance to these firms is republicized by the Fed.

5. The Process of Reopening the ODGF Firms

March 26, 1985: 18 of the S\&Ls are fully open, with only Home State and a few others fully closed. Only 2 or 3 experience continuing lines of depositors seeking withdrawals.

April 2, 1985: Out-of-state bid for Home State announced from Chemical. Deal said to require state to ante up at least $\$ 80$ million.

April 3, 1985: Deadline for counterbids from in-state institutions. One received, but later withdrawn.

April 8, 1985: 5 more institutions fully open, for a total of 39; most others remain partially open.

April 11, 1985: Injunction handed down against using ODGF funds to assist Chemical Bank purchase of Home State.

April 16, 1985: Chemical bid for Home State set at roughly $\$ 50 \mathrm{mil}$. (\$21 mil. entry fee plus $\$ 30$ mil. in new capital); estimates $\$ 90-\$ 129$ mil. in state funds required to keep depositors whole. (Request for state aid set at $\$ 125 \mathrm{mil}$. after audit.)

May 2, 1985: Ohio House passes $\$ 91$ million appropriation.

May 9, 1985: Ohio Senate passes $\$ 91$ million bill. Issue moves to Conference Committee. Possibility of in-state bid from Transohio introduced in Senate bill.

May 16, 1985: Conference committee reports out a $\$ 125$ mil. depositor bail out bill.

May 17, 1985: Senate deadlocks on Conference Committee bill at 16-16. A cynic might interpret this as a way of advertising a vote for sale.

May 21, 1985: Bill passes Senate 17-16. Chase and Ahmanson takeovers of other weak S\&Ls is finalized.

May 29, 1985: American Financial Corporation subsidiary Hunter S\&L outbids Chemical by $\$ 5 \mathrm{mil}$. Permits an in-state and non-cross-industry acquisition to occur. To a large extent the takeover is financed by FSLIC guarantees of Hunter. Hunter subsequently sells off $2 / 3$ of acquired branches to Ameritrust and First National Cincinnati Corp.

June 14, 1985: Home State offices re-open under new names.

June 20, 1985: Federal court orders liquidation of ESM. Bankruptcy trustee reports a recovery of only $\$ 23 \mathrm{mil}$. from ESM assets.

mid-December, 1985: Depositors of one institution (Valleywood Savings Association of Cincinnati) still face limitation on monthly withdrawals. Two institutions have not yet reopened at all (located in Steubenville and DeGraf).

Late December, 1985: Closed ODGF institution in Steubenville reopens.

January 12, 1986: Last of closed ODGF institutions, People Savings of DeGraf, opens as Midwest Savings.

March 24, 1986: Valleywood offices open under new ownership, ending the last instance of depositor inconvenience.

6. Subsequent Legal Efforts to Designate Scapegoats and Recover State Monies

November 6, 1986: State of Ohio wins in federal court a $\$ 34 \mathrm{mil}$. settlement from ESM's former auditor.

December 13, 1986: State grand jury indicts five Home State and ESM executives on felony charges.

March 30, 1987: State court sentences Warner to 3-1/2 years in prison and orders him to pay $\$ 22 \mathrm{mil}$. in restitution to the State.

March 31, 1987: Former Home State President, Burton Bongard, is sentenced to 10 years in prison and ordered to pay $\$ 114 \mathrm{mil}$. in restitution. Sources: Newspaper and magazine accounts; Federal Reserve Bank of Cleveland,
1985 Annual Report. 
lack of information on the market values of troubled institutions' individual assets and liabilities makes depositor runs a rational response to bad news and tends to prolong any insolvency crisis by complicating and delaying regulatory efforts to measure the size of asset shortfalls. Sixth, once the size of an insurer's insolvency has been determined, political forces unleashed by the process of negotiating the distribution of insurer losses across different classes of taxpayers have a tendency to impose especially heavy burdens on all surviving close competitors of the insolvent entities.

While all six points deserve study, the first two are treated extensively in other sources (e.g., Kane, 1985) and the third is an obvious consequence of bureaucratic competition between state and federal agencies and of opportunities for managers to corrupt individual accountants and investigators. Only the last three points receive amplification here.

3. Myopic Assessments of the Benefits and Costs of Restricting Information Flows

Restricting the flow of information on insured institutions' earnings and financial condition has the benefit for agency heads and for politicians of insulating them to a large extent from timely outside criticism of their performance as regulators. Voters can't knock what they can't see. This insulation increases public servants' personal autonomy, their immediate opportunities for reappointment or reelection, and their current value to potential outside employers. Having an option to understate the number and extent of troubled firms permits regulators and politicians to defer taking either responsibility or corrective action, if not indefinitely, at least until a politically or economically more convenient time. This option is valuable for two reasons. First, managers and stockholders of insolvent firms may be willing to pay a high price in political contributions for authorities to overlook their insolvent condition. Second, in the short run, the option of 
concealing a developing problem may be used to simplify the jobs of individual regulators and politicians and cosmetically to enhance their current reputations and immediate economic and political prospects by making their efforts appear far more successful to outside observers than they truly are.

Delayed insolvency resolution generates financial and political costs. Available evidence indicates that continually delaying the treatment of insolvency problems over long periods of time is bound to increase the discounted present value of the amount of insolvency observed (Barth, et al., 1986). Whether recognized fully or not, the political cost of having government regulators shape deposit institutions' information system and carry out their monitoring functions in secret is that the public is led to hold politicians and regulators at least partly responsible for whatever de jure insolvencies emerge. When a massive insolvency is observed, victimized depositors are bound to view weaknesses in the informational system and ineffective monitoring by public servants as governmental failures for which they should be recompensed. No matter how carefully formal arrangements may limit the government's de jure obligations, the government's de facto responsibility for overseeing the solvency of insured institutions imposes on government officials a conjectural obligation to make good the bulk of the losses that de jure insolvencies threaten to visit on individual depositors.

The frequency of Congressional and Presidential elections and the rapid turnover of agency heads makes it reasonable for regulators and politicians to accept a more myopic tradeoff of clear and immediate benefits for distant and highly uncertain penalties than the representative taxpayer might be expected to prefer. Authorities must discount potential bailout costs not only for their futurity but also for the probability that these costs may accrue largely to rival politicians or to the successors of current officials (who may well belong to a rival party) rather than to themselves. This second round of discounting makes myopic officials all the more myopic. 
4. The Rationality of Runs in the Face of Politically Managed Information Flows

During the two months of political jockeying that followed the shutdown of the ODGF, Home State depositors who had not bothered to participate in the run objected vociferously to being labeled "unsophisticated." Spokespersons for these depositors claimed that their only mistake was "to believe politicians' assurances that their money was safe." Whether or not such misplaced trust can be classified as an archetypical form of naivete, it is clear that financially sophisticated depositors recognized that State authorities made assurances that went beyond their knowledge base.

Although accounting data available in March 1985 could not tell State officials whether Home State and the ODGF were economically solvent, other evidence suggested that these entities were at the time deeply under water. As highly leveraged long lenders and short borrowers, most S\&Ls found that the run-up in interest rates observed since 1965 had lor.g since wiped out the economic value of their contributed capital. For years, the continued viability of these firms depended entirely on the credibility of deposit-insurance guarantees. In turn, the value of these guarantees did not rest on the accumulated reserves of state and federal deposit-insurance agencies. At all deposit-insurance agencies, reserves had fallen below the value of the unrealized losses that a careful analyst would assess to be potential claims against these reserves. Rather, the value of these guarantees depended on the conjecture that, in a crisis, incumbent politicians (no matter what their party affiliations happened to be) would invariably find it in their joint interest to recapitalize insolvent deposit-insurance funds.

During the run on Home State and its immediate aftermath, the applicability of this rational conjecture was undermined (albeit temporarily) in several ways. First, anyone familiar with the information system that State regulators had to work with recognized that the Governor's assurances as to the solvency of Home 
State and the adequacy of ODGF reserves clearly exceeded his capacity to know. This raised doubts about his veracity and his financial acumen. Second, his political ties to Home State's chief executive officer raised the possibility that conflicts of interest might be clouding his judgment. Third and most important, partly because of partisan skirmishing, the Governor and legislature simultaneously refused to backstop ODGF losses in the Home State failure and contributed only $\$ 50$ million of State funds to a successor fund that was being asked to guarantee almost $\$ 4$ billion in deposits at the 68 surviving S\&Ls. Depositors of economically insolvent former ODGF member firms saw these actions as an attempt to get the Ohio taxpayer off the hook for unrealized losses at their firms, too. Even though engaging in a run on these institutions cost a depositor the sure time and trouble of standing in line and establishing new depository connections, doing so would cut off his (or her) exposure to losses from this unexpected turn in State financial policy. Net returns to an individual from running would grow with the size of his deposit balance and his perception of the size of the unrecorded insolvency at his Stateinsured S\&L. For all depositors, the incentive to withdraw deposit balances became stronger as State politicians tried to pass the buck.

In contrast to calling a banking holiday, the accepted way to stop a run is to keep an institution's offices open and to convince people in line and those contemplating joining them that the firm or its guarantor is able and willing to meet their demands. When a series of deposit institutions are simultaneously threatened by insolvency, the government's first job parallels that of the triage performed by medical officers in combat situations. It needs to decide formally and in a credible manner which should close and which can safely remain open. In implementing an indefinite banking holiday, State officials underscored their inability to distinguish solvent institutions from insolvent ones. At the same time, they made it harder for the stronger ODGF institutions to maintain the confidence of their depositors or, by opening their books, to gain support from outside lenders. 
The loss of confidence spread to other state's deposit-insurance systems. In Massachusetts and Pennsylvania, for example, institutions insured by state-sponsored corporations came under pressure from March on. It is particularly instructive to contrast the regulatory approaches followed in North Carolina and Maryland. In North Carolina, a well-capitalized and well-run private deposit-insurance corporation acted to strengthen its system while implementing a plan to phase itself out of the business in an orderly manner. It urged its clients to apply for federal coverage immediately. In Maryland, authorities followed a completely opposite line of action, claiming that for the Maryland legislature to prepare publidy for a run would undermine faith in the Maryland system and generate more trouble than it would save. In May 1985, Maryland found itself limiting withdrawals at stateinsured institutions when it experienced a similar insolvency at the second-largest institution in its state-sponsored insurance system. North Carolina avoided the systemic problems Maryland experienced. This can be attributed in part to the unwillingness of Maryland authorities to swallow the unpleasant medicine of producing reliable information and shoring up its troubled insurance fund in timely fashion.

Rumors that a deposit institution or its insurer are insolvent are hard to refute when reliable information on their current financial condition simply does not exist. In the short term, authorities can most reliably maintain confidence not merely by denying the insolvency, but by demonstrating their willingness to back up the troubled entity. The more likely it is that politicians will fail to cover the losses of any class of depositor in full and in short order, the more sensible it is for depositors in that class to move their funds when credible flows of adverse information occur and/or depositor runs develop. If the troubled entity either turns out to be solvent or is bailed out with public funds, ex-depositors lose only the time and trouble of switching their business to a new firm. However, if an institution 
they could leave is eventually closed on disadvantageous terms, continuing depositors' percentage exposure to losses increases with every dollar of deposits that succeeds in leaving the firm before its demise becomes official.

\section{The Distribution of Bailout Costs}

Resolving the Home State insolvency cost Ohio and federal taxpayers in two ways. First, Ohio taxpayers had to kick in roughly $\$ 120$ million to Hunter Savings, which outbid Chemical Bank for the right to acquire Home State's institutional corpse. Federal taxpayers share in this burden to the extent that Ohio taxpayers subsequently deduct the incremental taxes from their federal tax bill. Second, taxpayers had to pay the freight for recapitalizing the weakest of the 68 unrelated S\&Ls formerly insured by the ODGF.

Because it was made essentially in cash, the first charge is easy to value. What is hard to assess is the extent to which these costs will ultimately be recovered as a result of legal settlements, the extent to which the incremental taxes were shifted to federal taxpayers, and the extent to which Hunter Savings' $\$ 26$ million dollar bid was ultimately underwritten by federal taxpayers through FSLIC guarantees of Hunter itself. (Parallel issues arise in the Steubenville, DeGraf, and Valleywood deals.)

Neither type of assessment is attempted here. The rest of this section seeks instead to identify the conceptual components of the implicit costs of recapitalizing the 68 S\&Ls closed in the banking holiday.

One element of this cost may be identified with the time that various depositors of the 68 institutions were unable to withdraw deposits freely. At least some of these depositors and some of the parties with which they wished to do business suffered costly disruptions in their affairs. Moreover, firms that were on the verge of closing anyway gained the right to keep interest-rate bets on the table 
and, with Home State depositors, were able to develop additional political leverage on State legislators. The consequences of these further plays and disruptions must be counted as part of the cost of managing the ODGF failure.

A second element consists of a reduction in the value of customer relationships at each of the 68 institutions. The holiday is bound to have alienated some depositors and to have persuaded others at least to diversify their deposit balances over a wider class of institutions and deposit insurers. This damage is also timerelated, in that for solvent firms a speedy determination of the viability of ODGF firms and a policy of timely triage using some form of modified depositor payoff would have lessened losses of this type.

The third element consists of the ex ante cost to Ohio taxpayers of transferring to FSLIC future liability for guaranteeing the deposits of reopened S\&Ls. Although hard to evaluate, the present value of the interim contingent indemnifications the State promised the FSLIC on the almost-\$3.8 billion in deposits whose guarantees FSLIC took over was appreciable. The risk associated with this gamble cannot be ignored just because the State appears to have won its bet. Given the average extent of these firms' de facto undercapitalization and the volatility of the economic environment, it is doubtful that these contingent commitments could have been sold in the open market for less than 1 to 3 percent of the amount guaranteed. This implies an additional cost to Ohio taxpayers of between $\$ 38$ and $\$ 112$ million.

The fourth cost of bailing out the ODGF is perhaps the subtlest of them all. This component consists of the capitalized value of the entry privileges that Ohio politicians sold to out-of-state acquirers of moribund firms. The entry fees that Ohio politicians collected from the likes of Chase Manhattan and Ahmanson came out of the hides of Ohio banks and S\&Ls. This is because they may be seen to have owned all "beneficial" interests in the entry barriers whose conditional lifting was 
conveyed. One does not have to favor such barriers to recognize that Ohio trade associations had won and maintained them by investments in lobbying and other forms of political activity. Moreover, State officials may have sold these privileges too cheaply. Putting regulatory privileges on the auction block for distress sale is not a good way to maximize the price at which they are sold.

The fifth and final cost belongs entirely to federal taxpayers. It consists of massive Federal Reserve and Federal Home Loan Bank System efforts to keep the 68 ODGF survivors open during the week after the Home State failure and to assist these firms to transfer speedily to FSLIC insurance after the banking holiday: These costs consist of below-market lending, an enormous reallocation of federal examination efforts, and (although FSLIC officials may not have bent their standards in any way) lighter-than-market capital requirements that FSLIC sets in qualifying clients.

6. Lessons for Players in the Parallel Federal Game

This paper's title asks what lessons different parties should learn from the crisis. As a way of summarizing the previous analysis, this section lists the major players in what is a continuing and multilayered game of deposit-insurance "chicken" and the lessons they might draw from the ODGF debacle.

$\underline{\text { Politicians and Regulators. Politicians and regulators should learn at least four }}$ lessons. First, the absence of market-value reports (even in the form of information that is held in confidence and not made available to the marketplace) encourages individual insolvencies and makes them hard to unwind promptly in cases where de facto insolvencies become public knowledge. Second, in the face of widespread economic insolvency and the increasing perfection of financial markets, political efforts to slip financially off the hook for unrealized deposit-institution losses are bound to subject undercapitalized deposit-insurance agencies to the 
pressure of client runs. Third, when the dust settles, the regulatory bureaus that are held responsible for an observed crisis will lose clients and administrative resources. Similarly, politicians who can be made to appear responsible will lose future electoral support. Fourth, half-baked efforts to stop an incipient run can easily make matters worse. In the face of a run, governmental assurances of an institution's solvency that are not backed by reliable information can undermine confidence in the government itself, as can inadequate efforts to recapitalize a threatened insurer. The $\$ 50$ million injection of State funds the Ohio legislature first voted was so smaij as to insult the inteiligence of most depositors. Sophisticated depositors saw that the mandated S\&L "contribution" of \$40 million provided no net increase in resources to the threatened firms so that, in pretending to create a $\$ 90$ million fund, State legislators were being less than forthright. \$90 million was probably too little anyway. Surviving S\&Ls had to write off about \$76 million in capital in the ODGF shutdown. It would have been safer to establish a fund whose aggregate size or reserve ratio equalled that of the prefailure ODGF. This would have required at least $\$ 120$ million in State funds. Given existing surpluses in state income-tax collections and in the lottery, an appropriation of this size could have been handled as a commitment (i.e., as a contingent liability) without too much pain.

Politicians and regulators need to recognize that what transformed preexisting structural imbalances into a full-fledged crisis was not the insolvency of Home State Savings, but the absence of reliable information on the condition of other ODGF-insured S\&Ls and authorities' failure to enunciate in timely fashion a credible policy for resolving the fallout of further insolvency generated by Home State.

Unlike the Governor of Ohio, federal politicians have so far refused to face up to the need to protect federal taxpayers from the secularly increasing costs of 
FDIC and FSLIC guarantees. As long as federal guarantees are underpriced and unreported, risk-taking at federally insured institutions will grow. Unless meaningful deposit-insurance reform is undertaken, bureaucratic breakdowns similar to that Ohio experienced will occur eventually in the federal system. Regulators and politicians need to think through the problems such a breakdown could create and set up mechanisms to deal with them.

If faced with a series of official S\&L insolvencies that exhaust FSLIC reserves, a politically attractive solution that has the look of a contingency plan is for Congress to merge FSLIC into the FDIC. Given the solvency problems that the FDIC fund already faces on its own, I believe that merging the two funds in the midst of a crisis in confidence might prove a recipe for disaster. Unless Congress and taxpayers are prepared to pledge unlimited amounts of crisis aid, the only effective alternatives are to recapitalize the federal insurance funds and to rationalize their information systems before a bureaucratic breakdown actually occurs.

Taxpayers (Including Well-Capitalized Deposit Institutions). Appropriate lessons for federal taxpayers are equally harsh. The initial unwillingness of State authorities to back the ODGF reflects their closeness to taxpayers. Ohio politicians recognized that Ohio taxpayers didn't want to be riskbearers of last resort. However, at federal level, taxpayer obligations are more diffuse. The cost of FDIC and FSLIC guarantees has not yet surfaced as a political issue.

The first lesson for taxpayers to learn is that contingent government guarantees are not costless. This can be brought out in cartoon fashion by picturing Ohio politicians as marrying insolvent ODGF institutions en masse to FSLIC and various institutional acquirers while ODGF depositors cheer and bound and gagged taxpayers and Ohio banks grimace in pain. To bring deposit-insurance 
costs back under control, the market value of each insurance fund's contingent guarantees could be reported regularly in ways that taxpayers can understand and monitor.

The second lesson is that, when the burden of bearing unrealized losses is finally distributed, some taxpayers are bound to be hit harder than others. The most exposed taxpayers figure to be surviving close competitors of the institutions whose losses actually bring down the system. Firms of the same institutional type as those who fail must expect to face higher post-failure insurance fees, while they and other close competitors will watch legislators and regulators sell off hardearned regulatory privileges to entrants from outside the industry. To preserve their capital and markets in the long run, economically solvent institutions might begin to push for deposit-insurance reform.

It is important to note that in part healthy ODGF institutions contributed to their own victimization. It is hard to believe that all of them could have failed to learn of Home State's problems with ESM. As members of an insurance pool that required them to guarantee one another's liabilities, they faced incentives to monitor one another and to press for timely resolution of developing insolvencies. In the absence of an adequate State regulatory response to their whistle blowing, solvent institutions might have petitioned to switch their insurance to the FSLIC or (even better) the FDIC. In addition, well before any run actually began, ODGF firms might have established a continuing borrowing agreement with the Cleveland Fed as authorized by the 1980 Depository Institutions Deregulation and Monetary Control Act.

Depositors. The principal lesson for depositors is that insured deposits are not necessarily riskless, even when they are issued by an apparently well-capitalized firm. During the Ohio banking holiday depositors at economically solvent ODGF 
firms were held hostage to the interests of Ohio taxpayers and economically insolvent members of the ODGF insurance pool. To cope with deposit risk, depositors may want to diversify their funds across insurers and to demand information from their bank or savings institution that can let them assess for themselves what constitutes an adequate risk premium on the deposits they hold. 


\section{REFERENCES}

Barth, James R., R. Dan Bumbraugh, Jr., Daniel Sauerhaft, and George H.K. Wang, 1986. "Failure Costs of Government-Regulated Financial Firms: The Case of Thrift Institutions." Washington: Federal Home Loan Bank Board.

Federal Reserve Bank of Cleveland, 1986. "Unfoldings in Ohio." Annual Report 1985.

Kane, Edward J., 1985. The Gathering Crisis in Federal Deposit Insurance. Cambridge: The MIT Press.

Saulsbury, Victor L., 1985. "The Current Status of Non-Federal Deposit Insurance Programs." Issues in Bank Regulation, 8 (Spring), 3-19. 